\title{
Agglomeration and New Establishment Survival: A Mixed Hierarchical and Cross-Classified Model
}

\author{
Martijn J. Burger, Frank G. van Oort, and Otto Raspe
}

Accepted and forthcoming in: Karima Kourtit, Peter Nijkamp and Roger Stough (eds), Drivers of Entrepreneurship, Innovations and Regional Dynamics, Berlin: Springer

\begin{tabular}{|l|l|}
\hline ERIM REPORT SERIES RESEARCH IN MANAGEMENT \\
\hline ERIM Report Series reference number & ERS-2010-018-ORG \\
\hline Publication & April 2010 \\
\hline Number of pages & 33 \\
\hline Persistent paper URL & http://hdl.handle.net/1765/19519 \\
\hline Email address corresponding author & mburger@ese.eur.nl \\
\hline Address & Erasmus Research Institute of Management (ERIM) \\
& RSM Erasmus University / Erasmus School of Economics \\
& Erasmus Universiteit Rotterdam \\
& P.O.Box 1738 \\
& 3000 DR Rotterdam, The Netherlands \\
& Phone: + 31104081182 \\
& Fax: $\quad+31104089640$ \\
& Email: info@erim.eur.nl \\
& Internet: $\quad$ www.erim.eur.nl \\
\hline
\end{tabular}

Bibliographic data and classifications of all the ERIM reports are also available on the ERIM website: www.erim.eur.nl 


\section{ERASMUS RESEARCH INSTITUTE OF MANAGEMENT}

\section{REPORT SERIES}

\section{RESEARCH IN MANAGEMENT}

\begin{tabular}{|l|l|}
\hline ABSTRACT AND KEYWORDS \\
\hline Abstract & $\begin{array}{l}\text { Recent empirical studies in regional science and urban economics show that agglomeration } \\
\text { economies may be one source of the uneven distribution of economic activities and economic } \\
\text { growth across cities and regions. At the same time, the body of research into the importance of } \\
\text { agglomeration economies for the performance of firms is still growing. Such development is } \\
\text { necessary, as the theories that underlie agglomeration economies are microeconomic in nature, } \\
\text { but still insufficiently understood. In this study, we focus on the determinants of survival among } \\
\text { new establishments in the advanced producer services sector in the Netherlands. Employing a } \\
\text { mixed hierarchical and cross-classified probit regression, we introduce a model of establishment } \\
\text { survival that is specific to characteristics of the internal and external environment of the } \\
\text { establishment. Controlling for firm and sector characteristics, we conclude that location accounts } \\
\text { for about 4\% of the variance in the probability of survival of new establishments. We also find } \\
\text { that localization and urbanization economies have a positive effect on the survival of new } \\
\text { establishments. However, new establishments with large start-up sizes appear to profit more } \\
\text { from agglomeration economies than new establishments with small start-up sizes. }\end{array}$ \\
\hline Free Keywords & agglomeration economies, micro-macro link, new establishments, multi-level analysis \\
\hline Availability & The ERIM Report Series is distributed through the following platforms: \\
Academic Repository at Erasmus University (DEAR), DEAR ERIM Series Portal \\
Social Science Research Network (SSRN), SSRN ERIM Series Webpage \\
Research Papers in Economics (REPEC), REPEC ERIM Series Webpage
\end{tabular}




\title{
Agglomeration and New Establishment Survival: A Mixed Hierarchical and Cross-Classified Model
}

\author{
Martijn J. Burger, Frank G. van Oort \& Otto Raspe
}

\begin{abstract}
Recent empirical studies in regional science and urban economics show that agglomeration economies may be one source of the uneven distribution of economic activities and economic growth across cities and regions. At the same time, the body of research into the importance of agglomeration economies for the performance of firms is still growing. Such development is necessary, as the theories that underlie agglomeration economies are microeconomic in nature, but still insufficiently understood. In this study, we focus on the determinants of survival among new establishments in the advanced producer services sector in the Netherlands. Employing a mixed hierarchical and cross-classified probit regression, we introduce a model of establishment survival that is specific to characteristics of the internal and external environment of the establishment. Controlling for firm and sector characteristics, we conclude that location accounts for about $4 \%$ of the variance in the probability of survival of new establishments. We also find that localization and urbanization economies have a positive effect on the survival of new establishments. However, new establishments with large start-up sizes appear to profit more from agglomeration economies than new establishments with small start-up sizes.
\end{abstract}

Keywords: agglomeration economies, micro-macro link, new establishments, multi-level analysis

JEL classification: C21, O18, R1 


\section{The Firm in the "New Economics of Urban and Regional Growth"}

Innovative economic developments take place in urban areas and industrial clusters. Urban and regional planners, geographers and economists are interested in the forces that create, shape and maintain these concentrations of economic activities (Van Oort, 2004). Since the early 1990s, a growing empirical literature has emerged in the field of regional science and urban economics. It examines whether spatial circumstances give rise to agglomeration economies - external economies from which firms can benefit through co-location - that endogenously induce localized economic growth (Glaeser et al., 1992; Henderson et al., 1995; Combes, 2000; Rosenthal and Strange, 2003, Brülhart and Mathys, 2008). As this literature tends to combine the traditional urban economics and regional science literature with new growth theory (Romer, 1986; Lucas, 1988), Glaeser (2000) has dubbed this line of research the "New Economics of Urban and Regional Growth." Many of the empirical studies under this heading show that agglomeration economies may be one source of the uneven distribution of economic activities and growth across cities and regions. In their survey of empirical literature on the benefits of agglomeration, Rosenthal and Strange (2004) point out that the elasticity of productivity to city and industry size typically ranges between $3 \%$ and $8 \%$. However, the effects of agglomeration economies on localized economic growth generally differ across sectors, space, and time (Rosenthal and Strange, 2004; Van Oort, 2007; De Groot et al., 2009; Melo et al., 2009; Neffke, 2009; Burger et al., 2010).

At the same time, relatively little is known about the importance of agglomeration economies for the performance of firms (Acs and Armington, 2004; Martin et al., 2008). Many empirical studies on agglomeration use aggregated data with cities or city-industries as the basic reference unit. Hence, these studies provide only limited insights and weak support for the effects of agglomeration economies on firm performance. Regional-level relationships are not necessarily reproduced at the firm level because information on the variance between 
firms is lost when using aggregated data. Hence, even if regions endowed with a greater number of agglomeration economies grow faster, this conclusion cannot be generalized to firms. In the social sciences, this problem is referred to as the "ecological fallacy" (Robinson, 1950) or the “cross-level fallacy” (Alker Jr., 1969).

In addition, agglomeration effects found in area-based studies can be compositional (Macintyre et al., 1993). For example, articles in the economic and industrial organization literature often argue that large firms are more likely to grow compared to small firms due to internal economies of scale. Hence, a location may be fast-growing due to the concentration of large firms rather than the localization of externalities or the external economies of scale present. This has been shown in the work of Combes et al. (2008) and Mion and Naticchioni (2009) on spatial sorting and spatial wage disparities. In addition, Baldwin and Okubu (2008) show that the agglomeration of productive firms may simply be a result of a spatial selection process in which more productive firms are drawn to dense economic areas. For this reason, it remains unclear whether geographical differences are an artifact of location characteristics (e.g., agglomeration economies) or simply caused by differences in business and economic composition. This endogeneity problem makes it even more difficult to draw inferences about firms when using cities or regions as the lowest unit of analysis.

Thus far, only a few studies have used firm-level data to assess the effect of agglomeration economies on firm performance. Audretsch and Dohse (2007) find that German firms located in a knowledge-based cluster grow faster than firms located in a region less endowed with knowledge resources. Henderson (2003) considers the productivity effect of employment density in a plant's own county versus neighboring counties. Using industry and time dummies, he finds that a $10 \%$ increase in employment in a plant's own county increases the productivity of a plant by $0.8 \%$ in the high-tech industry. Using French firmlevel data (both manufacturing and services), Martin et al. (2008) find that doubling the size 
of the firm's sector increases firm productivity by 4-5\%. Baldwin et al. (2008) find similar results for the effect of own industry size (in terms of buyer and supplier networks, labor market pooling and knowledge spillovers) on firm productivity in five broad manufacturing sectors in Canada. These studies find no effect of city size on firm productivity.

Although the relative shortage of firm-level evidence in the agglomeration economics literature can mainly be ascribed to data limitations and confidentiality restrictions, this is remarkable nevertheless because the theories that underlie agglomeration economies are microeconomic in nature (Martin et al., 2008). In other words, agglomeration economies do not directly foster regional economic growth, but do so only indirectly, through their effect on firm performance. In this chapter, we focus on the determinants of the survival of new establishments in the advanced producer services sector in the Netherlands. Employing a mixed hierarchical and cross-classified probit regression, we introduce a model of firm survival that is specific to characteristics of the internal and external environment of the firm. This external environment may consist of several components, such as its location, sector or club (location-by-sector). We add to previous studies in three ways. First, we explicitly disentangle the location effect from the firm and sector effect. Second, we analyze whether firms benefit from agglomeration economies asymmetrically in relation to their size. Third, we focus on new establishment survival in advanced producer services; an industry not researched much yet. Controlling for firm and sector characteristics, we find that location accounts for about $4 \%$ of the variance in the probability of survival of new establishments. We find that localization and urbanization economies have a positive effect on the survival of new establishments. However, new establishments with large start-up sizes tend to profit more from agglomeration economies than new establishments with small start-up sizes.

\section{The Macro to Micro Link in Agglomeration Economics}




\subsection{Agglomeration economies}

The origin of the agglomeration economies concept can be traced back to the end of the $19^{\text {th }}$ century. At the fin de siècle, the neoclassical economist Alfred Marshall aimed to overturn Malthus' and Ricardo's pessimistic (but influential) predictions on the co-evolution of economic and population development. He introduced a form of localized aggregate increasing returns to scale for firms. In his seminal work, Principles of Economics (Book IV, Chapter X), Marshall (1890) mentioned a number of cost-saving benefits or productivity gains external to a firm. He argued that a firm could benefit from co-location with other firms engaged in the same sort of business. Marshall considered these agglomeration economies to be uncontrollable and difficult to regulate, as well as immobile or spatially constrained.

Marshall (1890) focused on a local specialist labor pool, the role of local knowledge spillover, and the existence of non-traded local inputs. In contrast, Hoover (1948), Ohlin (1933) and Isard (1956) allocated the sources of agglomeration advantages into internal economies of scale and external economies of scale in the form of localization and urbanization economies. Production cost efficiencies realized by serving large markets may lead to increasing returns to scale in a single firm. There is nothing inherently spatial in this concept, other than that the existence of a single large firm in space implies a large local concentration of employment (Van Oort, 2004). However, external economies are qualitatively very different.

Whether due to firm size or a great number of local firms, a high level of local employment may allow for the development of external economies within a group of local firms in a sector. These are known as localization economies. The strength of these local externalities is assumed to vary, implying that they are stronger in some sectors and weaker in others (Duranton and Puga, 2000). The associated economies of scale comprise factors that reduce the average cost of producing outputs in that locality. Following Marshall (1890), a 
spatially concentrated sector can exert a pull on (and uphold) a large labor pool that includes workers with specialized training in the given industry. Obviously, this reduces search costs and increases flexibility in appointing and firing employees. Moreover, a concentration of economic activity in a given sector attracts specialized suppliers to that area, which in turn reduces transaction costs. Finally, agglomerated firms engaged in the same sector can profit from knowledge spillover, as geographic proximity to other actors facilitates the diffusion of new ideas or improvements related to products, technology and organization.

On the other hand, urbanization economies reflect external economies passed to enterprises as a result of savings from the large-scale operation of the agglomeration or city as a whole. Thus, they are independent of industry structure. Relatively more populous localities, or places more easily accessible to metropolitan areas, are also more likely to house universities, industry research laboratories, trade associations and other knowledgegenerating institutions. The dense presence of these institutions, which are not solely economic in character but also social, political and cultural, supports the production and absorption of knowledge, stimulating innovative behavior and differential rates of interregional growth (Harrison et al., 1997). However, areas that are too densely populated may also result in a dispersion of economic activities due to pollution, crime or high land prices. In this respect, one can speak of urbanization diseconomies.

Agglomeration economies are more complex than Marshall originally presented. Quigley (1998), for instance, describes additional features embedded in the categorization but not recognized for their individual value. These include scale economies or indivisibilities within a firm, the historical rationale for the existence of productivity growth in agglomerated industries in the first place (Isard, 1956). In consumption terms, the existence of public goods leads to urban amenities. Cities function as ideal institutions for the development of social contacts, which correspond to various kinds of social and cultural externalities (Florida, 
2002). Moreover, agglomeration economies may provide greater economic efficiency growth due to potential reductions in transaction costs (Martin and Ottaviano, 1999). The growing importance of transactions-based explanations of local economic productivity growth is a logical outcome of the interaction between urban economies and knowledge-based service industries (Castells, 1989). They have also become more important recently. Lastly, Quigley (1998) points to the law of large numbers regarding the possibility of fluctuations in the economy. Fluctuations in purchases of inputs are usually imperfectly correlated across firms, as are the sales of outputs across buyers. As such, opportunities to pool supplies imply that firms are required to hold fewer inventories.

\subsection{From Macro to Micro}

The features of agglomeration economies described above may explain why regions characterized by an agglomeration of economic activities tend to exhibit higher economic growth (McCann and Van Oort, 2009). Despite the focus in the empirical literature on the relationship between agglomeration economies and regional growth as a macro-level phenomenon, the underlying theory of agglomeration contains both macro- and micro-level propositions (see Rosenthal and Strange, 2004). Although these propositions begin and end at the urban or regional level, they recede at the level of the individual firm. Coleman (1990) explored this fact in his bathtub model (also known as the "Coleman boat”), concluding that system-level phenomena (e.g. agglomeration) influence system outcomes (e.g. regional economic performance) through their effect on firms' orientations and performance. In this respect, performance differences between regions cannot be perceived as a direct result of macro-economic differences between regions. Instead, they are by-products of firms' individual behaviors. 
Firms are interested in seeking agents whose production function is partly determined by the region or city in which they are embedded. This is influenced by the opportunities (agglomeration economies) and constraints (agglomeration diseconomies) present in this external environment (Granovetter, 1985; Grabher, 1993). In turn, differences in opportunities and constraints across regions generate differences in firm performance and, hence, in regional performance. Firms optimize their own performance but do not strive for regional growth. This phenomenon is more explicitly described as follows (see Figure 1):

1. The region in which a firm is embedded generates opportunities and economic constraints for firms located in that region through agglomeration economies and agglomeration diseconomies (macro-to-micro transition).

2. Firms with more economic opportunities and less economic constraints (Proposition 1) tend to perform better in terms of survival chances, employment growth or productivity growth (purposive action).

3. Regions containing successful firms (Propositions 1 and 2) exhibit higher economic growth. Regional performance is here conceptualized as the weighted sum of the firms' performances (micro-to-macro transition).

4. Regional performance affects regional circumstances, resulting in a feedback loop. In this fashion, the model can be linked to the evolutionary development of regions.

Two features of this theoretical model call for clarification. First, the firm's external environment consists not only of the location (physical environment), but of other components, such as the sector in which the firm is embedded (functional environment, Lambooy, 1993). For example, firms nested within the same sector share the same technologies and are affected by the same labor market policies and product life cycle. 
Second, not all opportunities and constraints facing a firm are related to macro-level properties, such as initial firm size, age or entrepreneurship (Santarelli and Vivarelli, 2007). However, even when constraints and resources are firm-based, to what extent their effect is independent of the external environment often remains debatable. In this chapter, we focus on the first two propositions and examine to what extent the macro-micro link exists in agglomeration economics.

Figure 1: Macro- and micro-level propositions: effects of regional circumstances on regional economic growth.

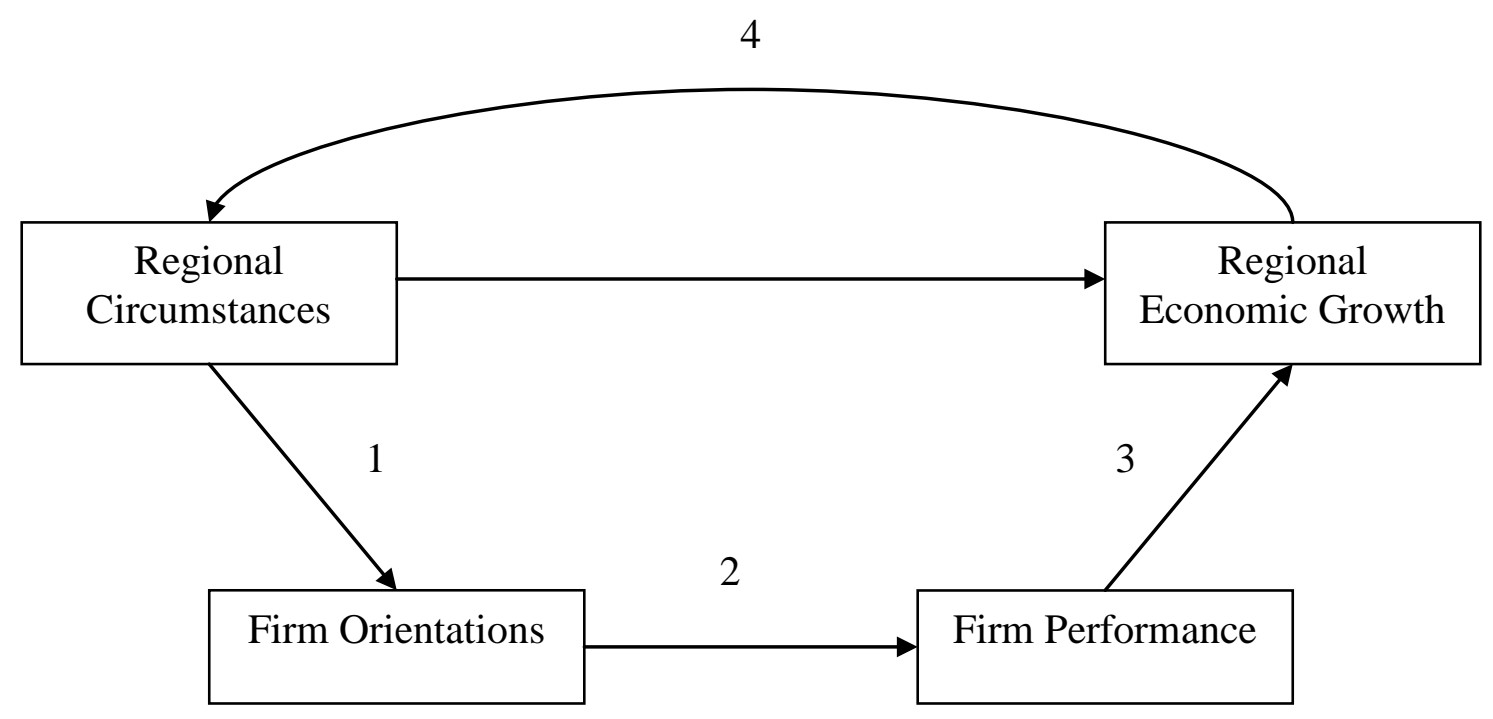

\section{New establishment survival in advanced producer services}

In order to examine the relationship between agglomeration economies and firm performance, we concentrate on the survival of new establishments in the advanced producer services sector in the Netherlands. An obvious advantage of focusing on new establishments is that these are less constrained by previous decisions, such as past capital installments, which influence how they value the marginal worker and whether new employment is created 
(Rosenthal and Strange, 2003). In the absence of many establishment-level variables, we avoid the endogeneity problems that are often present in analyses using data on incumbent establishments.

There are many indications in the existing empirical literature that new establishments tend to benefit from agglomeration. The benefits of agglomeration extend beyond start-up rates. They are assumed to be important for processes subsequent to entry, such as employment and productivity growth (Stam, 2005). Questioning whether these externalities bestow new entrepreneurial start-ups with any competitive advantage, Geroski (1995) argues that growth and survival prospects of new firms will depend on their ability to learn from their environment, and to link changes in their strategic choices to the changing configuration of that environment. Related to this, Audretsch et al. (2006) find that opportunities for entrepreneurship, and therefore of knowledge-based start-ups, are superior when new firms are able to access externalities through geographic proximity to knowledge sources. The underlying argument is that a new firm that must generate its own knowledge capital will be limited by scale and time. It has neither the resources nor the experience to generate ideas. However, a new firm that uses external knowledge and ideas can leverage its own knowledge capital by standing on the shoulders of giants. In addition, the processes subsequent to entry are important, and survival is one of the main goals of a new firm. In line with Audretsch and Mata (1995), we argue that survival (and, later on, growth processes) subsequent to the entry is at least as important as the entry process itself. The post-entry performance of establishments reveals the selection process of markets. The section process enables some of the new entrants to survive and prosper, while others stagnate and ultimately exit.

Our selection of economic activities focuses on new establishments in 19 advanced producer services sectors (see Table 1). Although we realize that agglomeration theory is originally based on the concentration of manufacturing, so most empirical research has 
focused on this sector (Melo et al., 2009), we argue that advanced business services can profit extensively from agglomeration externalities, as advanced business services are among the most concentrated economic sectors in Europe (Brülhart and Traeger, 2005) and these kinds of activities involve the creation, accumulation and dissemination of knowledge (Miles et al., 1995). Advanced producer services are characterized by their heavy reliance on professional knowledge, both codified (explicit) and tacit (implicit). These can be considered a primary source of information and external knowledge; they can use their knowledge to produce intermediary services for their clients' production processes and they are typically supplied to business through strong supplier user interactions (Illeris, 1996; Muller and Zenker, 2001). Bennett and Smith (2002) find that customers of advanced producer services search for a supplier within a radius of 25 kilometers.

Table 1: Sectors in advanced producer services used in the analysis of new establishment

\begin{tabular}{|l|l|}
\hline$\#$ & Sector \\
\hline 1 & Warehousing and support activities for transportation \\
\hline 2 & Publishing \\
\hline 3 & Banks and insurance \\
\hline 4 & Financial services \\
\hline 5 & Real estate activities \\
\hline 6 & Rental and leasing activities \\
\hline 7 & Computer services activities \\
\hline 8 & Information services activities \\
\hline 9 & Legal services \\
\hline 10 & Accounting \\
\hline 11 & Market research \\
\hline 12 & Advertising \\
\hline 13 & Management consultancy activities \\
\hline 14 & Architectural and engineering activities \\
\hline 15 & Scientific and research activities \\
\hline 16 & Employment activities \\
\hline 17 & Office administrative, office and business support activities \\
\hline 18 & Services to buildings \\
\hline 19 & Telecommunication \\
\hline
\end{tabular}




\section{Putting theory into practice: a multi-level framework}

\subsection{Exploring the macro to micro link}

Hierarchical or multi-level modeling, which allows the micro- and macro-levels to be modeled simultaneously, is becoming an increasingly common practice in the social sciences. Goldstein (2003) and Moon et al. (2005) summarize recent overviews of area-based studies in relation to multi-level modeling.

Following Jones (2004), there are two distinct advantages to multi-level models. First, multi-level models offer a natural way to assess contextuality, or to what extent a link between the macro-level and micro-level exists. Applying multi-level analysis to empirical work on agglomeration starts from the simple observation that firms sharing the same external environment are more similar in their performance than firms that do not share the same external environment. This is due to shared agglomeration externalities. In this fashion, we can assess the extent to which variance in the survival rates of new establishments can be attributed to between-firm variance, between-area variance, or between-sector variance (McGahan and Porter, 1998). Hence, we are able to assign variability to the appropriate context (Bullen et al., 1997).

Second, multi-level analysis allows us to incorporate unobserved heterogeneity into the model by including random intercepts and allowing relationships to vary across contexts through the inclusion of random coefficients. Whereas "standard" regression models are geared at modeling the mean, multi-level analysis focuses on modeling variances explicitly. For example, the effect of urbanization externalities may vary across small and large firms or across sectors. This kind of complexity can be captured in a multi-level framework through the inclusion of random coefficients (Snijders and Bosker, 1999).

\subsection{A mixed hierarchical and cross-classified model}


Multi-level analysis has been concerned with modeling hierarchically nested structures (e.g., firms located in the same region are also located in the same country due to the nesting of the two levels). However, the external environment of the establishment may consist of several components that have a non-hierarchical nesting structure, as they are grouped along more than one dimension, or cut across hierarchies (Goldstein, 2003). For example, sectors are not nested in regions and vice versa. Hence, establishments can be in the same sector but located in different regions. These different facets of the external environment may explain variation in establishment performance.

Figure 2: A mixed hierarchical and cross-classified model of the external environment of new establishments

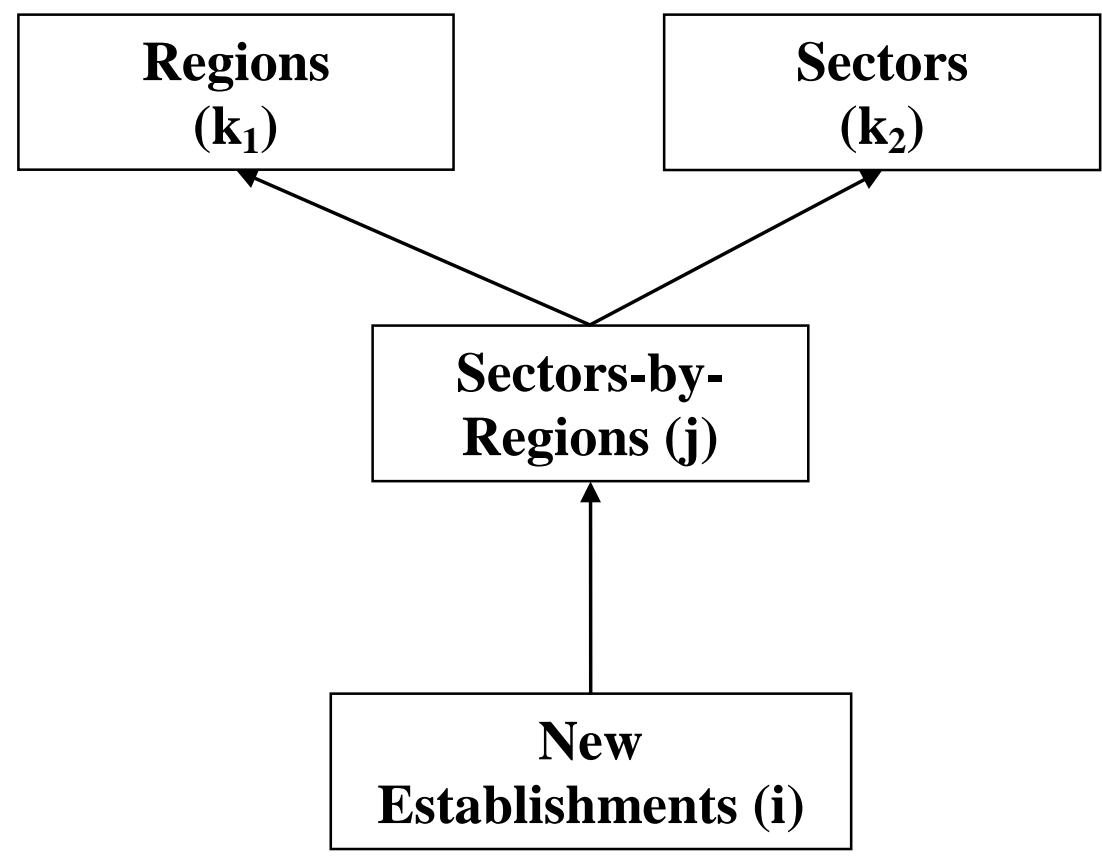

In our model, we distinguish between the following four classifications: 1) regions [40 NUTS-3 regions], 2) sectors [19 sectors in the advanced producer services], 3) sectors-byregions [40*19 $=781$ clubs], 4) establishments [46038 new establishments]. To begin with, 
establishments may be affected by the region in which they are located. As indicated earlier, these location factors may be general (to which all establishments in a given location are exposed) or sector-specific (restricted to a subset of establishments nested within a given sector in that location). However, establishments may also be affected by external factors that are not location-specific, but are common to all establishments within a given sector. As the classification of clubs is intersected by the classification of the sectors and the classification of the locations, it cannot be independently estimated. Hence, we should disentangle the general location factors and the nation-wide sector-specific factors from the sector-specific factors that are spatially bounded. The sector-specific effects that are location-specific are assessed at the appropriate sectors-by-regions or “club” level (Gordon and McCann, 2000). To illustrate this, we use a mixed hierarchical and cross-classified model (presented in Figure 2). We have a three-level model (with four classifications) with a random intercept for establishments at the lowest level and random intercepts for regions $(k 1)$, sectors-by-regions $(j)$, and sectors $(k 2)$ at the higher levels. More formally, we estimate the following base probit model for the probability of survival $y_{i j\left(k 1_{1} k 2\right)}$ of new establishments in the advanced producer services:

$$
\begin{aligned}
& y_{i j\left(k 1_{1} k 2\right)}=\text { Binomial }\left(n_{i j\left(k 1_{1} k 2\right)}, \mu_{i j\left(k 1_{1} k 2\right)}\right) \\
& \operatorname{probit}\left(\mu_{i j(k 1, k 2)}\right)=X_{i j(k 1, k 2)} \beta_{0}+u_{0 j\left(k 11_{0} k 2\right)}+v_{0 k 1}+v_{0 k 2} \\
& \text { where } u_{0 j(k 1, k 2)} \sim N\left(0, \sigma_{\mathrm{w} 0 j(k 1, k 2)}^{2}\right), v_{0 k 1} \sim N\left(0, \sigma_{v 0 k 1}^{2}\right), v_{0 k 2} \sim N\left(0, \sigma_{v 0 k 2}^{2}\right)
\end{aligned}
$$

in which the probability of survival of new establishments $\mu_{i j\left(k 1_{l} k 2\right)}$ is explained by the single fixed intercept term $X_{i j\left(k 1_{1} k 2\right)} \beta_{0}$, which is the average survival rate of new establishments in the advanced producer services. The three separate random terms $u_{0 j\left(k 1_{1} k 2\right)}+v_{0 k 1}+v_{0 k 2}$ 
are related to the intercept and mirror, the remaining residual variation at the higher levels. This differs from a typical regression model in that we assume that each sector-by-region $j$, region $k 1$ and sector $k 2$ has a different intercept. Note the mixed-hierarchical and crossclassified structure here: the indexing structure $\mu_{i j\left(k 1_{1} k 2\right)}$ refers to the $i^{\text {th }}$ establishment in the $j^{\text {th }}$ club, which is nested in region $k_{1}$ and sector $k_{2}$. This null model allows us to understand how to attribute variation in the probability of new establishment survival to various contexts.

The variance partition coefficient (VPC) can measure the extent to which the probability of survival of new establishments in the same club/region/sector resemble one other relative to those from new establishments in different clubs/regions/sectors. This figure may also be interpreted as the proportion of the total residual variation in survival that is due to differences between clubs, regions, or sectors. For example, the VPC for regions represents the percent of variation explained by the region level differences for firm $i$ in club $j$ and sector $k 2(2)$.

$V P C_{k 1}=\sigma_{v 0 k 1}^{2} /\left(\sigma_{w 0 j(k 1, k 2)}^{2}+\sigma_{v 0 k 1}^{2}+\sigma_{v 0 k 2}^{2}\right)$

In Equation (2), the term $\sigma_{\mathrm{w} 0 j\left(k 1_{1} k 2\right)}^{2}$ is the between-club variance, $\sigma_{v 0 k 1}^{2}$ is the between-region variance, and $\sigma_{\mathrm{vok} 2}^{2}$ is the between-sector variance. We assume that the probit distribution for the establishment-level residual implies a variance of 1 (Goldstein, 2003).

\subsection{Adding predictor variables and cross-level interactions}

So far, we have only partitioned the variability in the probability of survival of new establishments over regions, sectors-by-regions, sectors, and establishments. However, in order to see to what extent they explain the partitioned variability, we can add predictor 
variables to these classifications. More specifically, the predictors (or fixed parameters) we add here contain measures related to establishment characteristics, sector-by-region characteristics and region characteristics. Since we are mainly interested in the effects of regional and sector-by-region characteristics on firm performance, we include sector fixed effects $\left(\delta_{k 2}\right)$ by including sector dummies (based on the classification in Table 1) at the sector level. More formally,

$$
\begin{aligned}
& y_{i j\left(k 1_{1} k 2\right)}=\text { Binomial }\left(n_{i j\left(k 1_{1} k 2\right),} \mu_{i j\left(k 1_{1} k 2\right)}\right) \\
& \text { probit }\left(\mu_{i j(k 1, k 2)}\right) \\
& \begin{array}{l}
=X_{i j(k 1, k 2)} \beta_{0}+\beta_{10} X_{1 i j(k 1, k 2)}+\sum_{j=1}^{q} \beta_{q 0} X_{q j(k 1, k 2)}+\sum_{k: 1=1}^{r} \beta_{r 0} X_{r k 1}+\delta_{k 2} \\
+u_{0 j(k 1, k 2)}+v_{0 k 1}
\end{array}
\end{aligned}
$$

Where $u_{0 j(k 1, k 2)} \sim N\left(0, \sigma_{\mathrm{w} 0 j(k 1, k 2)}^{2}\right), v_{0 k 1} \sim N\left(0, \sigma_{v 0 k 1}^{2}\right)$

In Equation (3), the segment $\beta_{10} X_{1 i j(k 1, k 2)}+\sum_{j=1}^{q} \beta_{q 0} X_{q j(k 1, k 2)}+\sum_{k 1=1}^{r} \beta_{r 0} X_{r k 1}$ contains the predictor variables $X$ at the firm, club and region levels that enter the analysis. The subscripts $q$ and $r$ indicate the number of predictor variables included at the club and regional levels, respectively (please note that with respect to the establishment level, we only include initial establishment size, $X_{1}$ ). The $\beta$ s refer to the associated regression slope terms.

Equation (3) is a random intercept model. Only the intercept varies across clubs and regions. However, parameter estimates may also vary across different sub-populations. For example, the effects of localization and urbanization economies may vary over small and large firms. This can be modeled using a cross-level interaction between firm size $\left(X_{1}\right)$ and 
the respective agglomeration economies. Including firm size as predictor variable at the firm level, we obtain the following Equation (4).

$y_{i j\left(k 1_{1} k 2\right)}=$ Binomial $\left(n_{i j\left(k 1_{0} k 2\right), \mu} \mu_{i j\left(k 1_{1} k 2\right)}\right)$

probit $\left(\mu_{i j\left(k 1_{1} k 2\right)}\right)$

$$
\begin{aligned}
& =X_{i j(k 1, k 2)} \beta_{0}+\beta_{10} X_{1 i j\left(k 1_{0} k 2\right)}+\sum_{j=1}^{q} \beta_{q 0} X_{q j(k 1, k 2)}+\sum_{k=1}^{r} \beta_{r 0} X_{r k 1}+\delta_{k 2} \\
& +\sum_{j=1}^{q} \beta_{q 10} X_{1 i j(k 1, k 2)} X_{q j(k 1, k 2)}+\sum_{k 1=1}^{r} \beta_{r 10} X_{1 j j(k 1, k 2)} X_{r k 1} \\
& +u_{1 j(k 1, k 2)} X_{1 i j\left(k 1_{1} k k 2\right)}+v_{1 k 1} X_{1 i j(k 1, k 2)}+u_{0 j(k 1, k 2)}+v_{0 k 1}
\end{aligned}
$$

Where $u_{0 j(k 1, k 2)} \sim N\left(0, \sigma_{w 0 j(k 1, k 2)}^{2}\right), v_{0 k 1} \sim N\left(0, \sigma_{v 0 k 1}^{2}\right)$

In Equation (4), $\sum_{j=1}^{q} \beta_{q 10} X_{1 j i(k 1, k 2)} X_{q j(k 1, k 2)}+\sum_{k 1=1}^{r} \beta_{r 10} X_{1 i j(k 1, k 2)} X_{r k 1}$ now represent the cross-level interactions between establishment size and the club-level variables and between establishment size and the region-level variables, respectively, while $u_{1 j(k 1, k 2)} X_{1 i j(k 1, k 2)}+v_{1 k 1} X_{1 i j(k 1, k 2)}+u_{0 j(k 1, k 2)}+v_{0 k 1}$ represents the random part of the model. The expressions $u_{1 j\left(k 1_{1} k 2\right)}+v_{1 k 1}$ are the random slope parameters that make the effect of firm size on the probability of survival dependent on the club and region in which the firm is embedded. The cross-level interactions that aim to explain the random slopes can be interpreted as the variation of the effect of the club and region variables across small and larger firms. In the remainder of the chapter, we focus in particular on the interaction between firm size and the different agglomeration economies. However, it should be noted that the range of possible interactions is not limited to these variables. 


\section{Data and methodology}

\subsection{Data and Variables}

Data on employment at the establishment level was obtained from the LISA (Landelijk Informatie Systeem Arbeidsplaatsen - National Information System of Employment) database, an employment register that covers all establishments in the Netherlands for the period 19962006. For each firm, we retrieved detailed information about the number of employees, economic activity (sector) and geographic position. Our dependent variable, SURVIVAL (2000-2006) is a Boolean dummy variable measured at the level of the establishment, which takes the value 1 if a new establishment in 2000 or 2001 survived the first five years of its existence.

As indicated in our theoretical framework, we focus on two types of agglomeration economies: localization economies and urbanization economies. LOCALIZATION ECONOMIES, or sector-specific scale economies, are defined at the sector-by-region level and measured as the concentration of own-sector employment in the region under observation. URBANIZATION ECONOMIES, or economies available to all firms in a region irrespective of sector they are in, is defined at the region level and measured by the concentration of total employment, which arises from urban size and density.

Besides indicators for localization and urbanization economies, we introduce control variables related to the firm, sector-by-region, and region. At the establishment level, we take INITIAL FIRM SIZE into account, measured as the natural logarithm of the number of employees in the year the establishment was founded. Size represents the economies of scale available to a new establishment. Economies of scale, internal to the establishment, refer to the fact that the unit costs of production are a decreasing function of output. By explicitly differentiating between internal and external economies of scale, we try to account for compositional effects. 
With respect to the sector-by-region (club) level, the variable COMPETITION is introduced to control for market structure. COMPETITION is measured as the natural logarithm of the number of entries and exits in the regional sector between 2000 and 2006 divided by the number of firms in 2000. Finally, at the regional level, we have chosen to include R\&D expenditures and human capital stock as the main control variables. Regional $R \& D$ EXPENDITURES are measured as the natural logarithm of the $\mathrm{R} \& \mathrm{D}$ expenditures of firms, research institutes and government agencies in 2000. The HUMAN CAPITAL stock in a region is measured as the natural logarithm of the percentage of the workforce that is highly educated (ISCED 5-6) in 2000. Both the R\&D and the HUMAN CAPITAL indicators stem from the research of Broersma and Oosterhaven (2004).

\subsection{Estimation Strategy}

The mixed hierarchical and cross-classified models specified in the previous section are estimated using the MLWIN 2.10 software (Rashbash et al., 2008). More specifically, we estimate six models. First, we estimate a random-intercept probit model (Equation 1) for survival without including any predictor variables. The VPCs are derived from these models (Equation 2), which serve as a tool to indicate to what extent location matters by explicitly disentangling the between-location variance from the between-firm and -sector variance. Second, we estimate a random intercept probit model (Equation 3) to assess the importance of the different types of agglomeration economies in new establishment survival. Third, we estimate random coefficient models to assess whether the effect of agglomeration economies varies across firms of different sizes (Equation 4).

In Equations 3 and 4, we assume that the establishment-level predictor variables are uncorrelated with the club- and regional-level error terms and that the club-level predictor variables are uncorrelated with the regional-level error terms. However, both theoretically 
and empirically, such an assumption is difficult to meet. Not correcting for this would lead to inconsistent parameter estimates. However, as shown by Snijders and Berkhof (2007), the correlation between the lower level predictor variables and higher level error terms can be easily removed by including club- or region-level means of the lower-level predictor variables in the regression model, a procedure known as the Mundlak (1978) correction. Hence, our multi-level probit models are augmented with this correction.

\section{Empirical results}

\subsection{Partitioning the variance}

As indicated in the previous paragraph, one advantage of multi-level modeling is the decomposition of the variance. This has three higher-level classifications, in our case: 1) regions; 2) sectors; 3) sectors-by-regions (clubs). The variance partition coefficient (VPC) measures the extent to which the probability of survival of new establishments in the same club/region/sector resemble one other relative to those from new establishments in different clubs/regions/sector. Although the VPC is mainly a descriptive tool, it provides insight into the extent to which the region or sector matters for the performance of firms compared to firm characteristics. In empirical research on firm performance, the use of variance decomposition analysis dates back to the work of Schmalensee (1985), who disentangled sector and corporate effects from business unit effects. Today, this has resulted in a large empirical literature in industrial organization, which focuses on whether the appropriate unit of analysis is the firm or the industry (see Rumelt, 1991 and McGahan and Porter, 1997). However, location remains an under-studied factor in this type of analysis.

Table 2 shows the proportion of the total residual variation in new establishment survival in the advanced producer services sector that is due to differences between clubs, regions, or (sub)sectors. We see that firm survival (survival and growth) is mainly affected by 
internal (establishment) characteristics. More than $90 \%$ of the total variance is between establishment variance. The between-region variance is $3.3 \%$, while the between-club variance is $1.3 \%$. Although the external environment explains only a marginal amount of the variation in the probability of new establishment survival, we argue here that the region contributes to firm performance given the enormous diversity of firms. As we defined agglomeration economies as both region (urbanization economies) and club (localization economies) related, we argue that those externalities "explain" about 3.3-4.6\% of the variance in the probability of new establishment survival. In the next paragraph, we model the contributions of these agglomeration variables to new establishment survival.

Table 2: Variance partition coefficients (VPCs) for the survival of new establishments

\begin{tabular}{|l|c|}
\hline & $\begin{array}{c}\text { Model 1 } \\
\text { Survival }\end{array}$ \\
\hline VPC (firm) - between firm variance & $90.9 \%$ \\
\hline VPC (club) - between club variance & $1.3 \%$ \\
\hline VPC (region) - between region variance & $3.3 \%$ \\
\hline VPC (sector) - between sector variance & $4.5 \%$ \\
\hline $\mathrm{N}$ & 46038 \\
\hline
\end{tabular}

\subsection{Agglomeration economies and new establishment survival}

Table 2 shows the results of our model estimates. With respect to establishment size and survival opportunities (due to downscaling possibilities), we find a small positive and significant effect, with a marginal effect at the mean of 0.005 . This effect may be small due to the fact that our "sample" of new establishments mainly consists of smaller firms and that the heterogeneity of size in relation to the probability of survival is relatively low. This is in contrast with other studies, which find a much larger positive relationship between size and survival for incumbent firms (for example, see Audretsch and Dohse, 2007; Raspe and Van Oort, 2009). 
We now turn to the effect of agglomeration economies on the probability of new establishment survival in the advanced producer services sector. From the previous section, we already noticed a "solitary spatial effect." But looking into this deeper, we conclude that the concentration of own-sector employment (localization economies) has a small, positive effect on new establishment survival, with a marginal effect at the mean of 0.036 . The urban density effect, stemming from urbanization economies, has a much higher impact on new establishment performance in the advanced producer services. New establishments located in dense urban regions experience higher survival rates, where the marginal effect at the mean is 0.108. Hence, we conclude that new establishments in the advanced producer services sector have fewer difficulties surviving in cities.

But the relationship between agglomeration and new establishment survival might not be a fixed relationship over all establishments. On the contrary, we argue that some establishments (based on establishment-specific characteristics) profit more than others, or that externalities only appear for some types of firms. In this section, we test for so-called "cross-level interaction effects," interactions between variables measured at hierarchically structured data on different levels (Hox, 2002). We focus on initial firm size, analyzing the possibility that agglomeration economies are mainly effective for the larger start-ups.

It appears that initial establishment size has a significant slope variance (the basic underlying condition for the existence of cross-level interaction effects). Table 3 shows the results of the random coefficient models, where we allowed for the possibility that the effect of initial firm size can vary from region to region (regions have different slopes), including an interaction effect on size and localization and urbanization economies. The random part in Table 3 shows that the covariance between the region's intercept and slope is significant and positive. This positive covariance suggests that a higher intercept is associated with a higher slope. In other words, either larger firms perform better in some regions or their smaller 
counterparts perform less well in some regions. The question is whether the different agglomeration economies influence this relationship. To test this, we account for cross-level interaction effects in Model 4. We find that the interaction effects between initial establishment size and localization and urbanization economies are significant and positive. This means that larger start-ups profit more from own industry and urban density.

Table 3: Multi-level probit on new establishment survival

\begin{tabular}{|c|c|c|}
\hline & $\begin{array}{c}\text { Model } 3 \text { - PROBIT } \\
\text { survival }\end{array}$ & $\begin{array}{c}\text { Model } 4 \text { - PROBIT } \\
\text { survival }\end{array}$ \\
\hline Intercept & $0.153(.659)$ & $-0.041(.636)$ \\
\hline Initial Establishment Size (In) & $0.013(.007)^{*}$ & $-0.138(.131)$ \\
\hline Localization Economies (In) & $0.094(.053)^{*}$ & $0.083(.054)$ \\
\hline Competition (In) & $-0.085(.054)$ & $-0.087(.054)$ \\
\hline Urbanization Economies (In) & $0.277(.102)^{* * *}$ & $0.254(.098)^{* * *}$ \\
\hline Human Capital (In) & $-0.129(.146)$ & $-0.181(.138)$ \\
\hline R\&D Expenditures (ln) & $-0.064(.035)^{*}$ & $-0.064(.033)^{*}$ \\
\hline Est. Size * Localization Economies & & $0.022(.013)^{*}$ \\
\hline Est. Size * Urbanization Economies & & $0.051(.021)^{* *}$ \\
\hline Sector fixed effects & Yes & Yes \\
\hline Mundlak correction & Yes & Yes \\
\hline \multicolumn{3}{|l|}{ Random part } \\
\hline$u_{o j k 1}$ & $0.013(.002)$ & $0.015(.003)$ \\
\hline$u_{1 j k 1}$ & $0.009(.002)$ & $0.009(.002)$ \\
\hline$v_{0 k 1}$ & $0.023(.006)$ & $0.033(.008)$ \\
\hline$v_{1 k 1}$ & $0.008(.003)$ & $0.006(.002)$ \\
\hline \multicolumn{3}{|l|}{ Observations } \\
\hline Regions & 40 & 40 \\
\hline Sectors-by-Regions & 781 & 781 \\
\hline Establishments & 46038 & 46038 \\
\hline
\end{tabular}

\section{Conclusions and Discussion}


A large empirical literature examines whether spatial circumstances give rise to agglomeration economies - external economies from which firms can benefit through colocation - that endogenously induce localized economic growth. Many existing empirical studies show that agglomeration economies may be one source of the uneven distribution of economic activities and economic growth across cities and regions. At the same time, relatively little is known about the importance of agglomeration economies to the performance of firms. This absence is remarkable because the theories that underlie agglomeration economies are microeconomic in nature. Agglomeration economies do not directly foster regional economic growth, but do so indirectly through their effect on firm performance.

We analyzed this relationship by focusing on the determinants of the survival of new establishments in the advanced producer services sector in the Netherlands. Employing a mixed hierarchical and cross-classified logistic regression, we introduced a model of firm survival specific to characteristics of the internal and external environment of the firm. The external environment consists of several components, such as its region, sector or club (sector-by-region). Controlling for firm and sector characteristics, we find that location accounts for 3.3-4.6\% of the variance in new establishment survival. Although this spatial effect appears to be small at first sight - it was obtained that over $90 \%$ of the variance in the probability of new establishment survival is due to differences between establishments and the effect of location seems to be rather small at first hand - we still argue that "space matters significantly”, especially given the enormous establishment heterogeneity that exists.

We do not find evidence for the widespread hypothesis that larger firms have more survival opportunities. Agglomeration externalities, defined on the regional and sector-byregion levels, perform unevenly in relation to survival and (subsequent) growth of new producer service firms. Localization and urbanization economies do have a positive effect on 
new establishment survival. However, urbanization economies appear to be more conducive to new establishment survival in the advanced producer services industry than localization economies. Introducing cross-level interaction effects in our models, we find that larger startups profit from proximity to a concentration of own-sector employment and urban density with respect to survival opportunities. These outcomes have implications for policymakers. Region and sector conditions have a significant but relatively limited impact on business service firms' survival and growth prospects. Common and popular policies aiming at stimulating spatial producer service clusters (defined as clubs by sector-specific concentrations) may increase the survival chances of only the largest start-ups. In addition, larger urban areas exhibiting potentially larger urbanization economies have a more robust and distinct impact on new establishments. This suggests that localized policy measures should be limited to areas outside these largest economic agglomerations.

In this chapter, we have shown that multi-level analysis provides an analytical tool to assess and magnify the link between the macro-level and micro-level. Yet, there are some limitations to the use of multi-level analysis in spatial research. Multi-level analysis does not fully account for the spatial dependence present in data, in that it does not allow for the effect of neighboring regions on the performance of a firm. Spatial spillover effects between regions may notwithstanding be highly relevant and not accounting for this may underestimate the importance of 'space' in explaining the performance of firms. For example, R\&D and human capital are well known for spatial spillover effects. Viable solutions here would be to include spatially weighted independent variables in the model (e.g., Florax and Folmer, 1992), use a conditional autoregressive multi-level model (e.g., Breslow and Clayton, 1993) or employ a spatial multiple membership model (e.g., Browne et al., 2001). Combining such empirical strategies with a micro-macro framework will put the literature on agglomeration economics 
a step forward in answering the question to what extent the environment of firms is important for the performance of firms

\section{References}

- Acs Z, Armington C (2004) The impact of geographic differences in human capital on service firm formation rates. J Urban Ec 56: 244-278.

- Alker HR Jr (1969), A typology of ecological fallacies. In: Dogan M, Rokan S (eds) Quantitative ecological analysis. MIT Press, Cambridge, MA, pp 69-86.

- Audretsch DB, Dohse D (2007) Location: a neglected determinant of firm growth. Rev World Ec 143: 79-107.

- Audretsch DB, Keilbach M, Lehmann EE (2006) Mansfield's missing link: the impact of knowledge spillovers on firm growth. J Technol Transf 30: 207-210.

- Audretsch DB, Mata J (1995) The post-entry performance of firms: introduction. Int J Ind Organ 14: 413-419.

- Baldwin R, Okubu T (2006) Heterogeneous firms, agglomeration economies and economic geography. J Ec Geogr 6: 323-346.

- Baldwin R, Brown WM, Rigby DL (2008) Agglomeration economies: microdata panel estimates from Canadian manufacturing. Unpublished manuscript, Economic Analyses Research Paper Series, Statistics Canada.

- Bennet R, Smith C (2002) The influence of location and distance on the supply of business advice. Environ Plan A 34: 251-270.

- Breslow NE, Clayton DG (1993) Approximate inference in generalised linear models. J Am Stat Assoc 88: 9-25.

- Broersma L, Oosterhaven J (2004) Regionale arbeidsproductiviteit: niveau, groei en verklaring. Ministry of Economic Affairs, The Hague. 
- Browne WJ, Goldstein H and Rasbash J (2001) Multiple membership multiple classification (MMMC) models. Stat Model 1: 103-124.

- Brülhart M, Mathys, NA (2008) Sectoral agglomeration economies in a panel of European regions. Reg Sci Urban Ec 38: 348-362.

- Brülhart M, Traeger R (2005) An account of geographic concentration patterns in Europe. Reg Sci Urban Ec 35: 597-624.

- Bullen N, Jones K, Duncan C (1997) Modelling complexity: analysing betweenindividual and between-place variation - a multilevel tutorial. Environ Plan A 29: 585609.

- Burger MJ, Van Oort FG, Van der Knaap B (2010) Trattato sulla scala geografica delle esternalità di agglomerazione ed il MAUP (A treatise on the geographical scale of agglomeration externalities and the modifiable areal unit problem). Sci Reg 4: 19-39.

- Castells M (1989) The informational city. Information technology, economic restructuring and the urban-regional process. Blackwell, Oxford.

- Coleman JS (1990) Foundations of social theory . Harvard University Press, Cambridge, MA.

- Combes PP (2000) Economic structure and local growth: France 1984-1993. J Urban Ec 47: 329-355.

- Combes PP, Magnac T, Robin JM (2004) The dynamics of local employment in France. J Urban Ec 56: 217-243.

- Combes PP, Duranton G, Gobillon L (2008) Spatial wage disparities: sorting matters. J Urban Ec 63: 723-742.

- De Groot HFL, Poot J, Smit MJ (2009), Agglomeration externalities, innovation and regional growth: theoretical reflections and meta-analysis. In: Capello R and Nijkamp P 
(eds) Handbook of Regional Growth and Development Theories. Edward Elgar, Cheltenham, UK, Chapter 14.

- Duranton G, Puga D (2000) Diversity and specialisation in cities: why, where and when does it matter? Urban Stud 37: 533-555.

- Feldman MP, Audretsch DB (1999) Innovation in cities: science-based diversity, specialization and localized competition. Eur Ec Rev 43: 409-429.

- Fielding A, Goldstein H (2006) Cross-classified and multiple membership structures in models: an introduction and review. DfES, London, Research Report no. 791.

- Florax R, Folmer H (1992) Specification and estimation of spatial linear panel models: Monte Carlo evaluation of pre-test estimators. Reg Sci Urban Ec 22: 402-432.

- Florida R (2002) The rise of the creative class. Basic Books, New York.

- Frenken K, Van Oort FG, Verburg T (2007), Related variety, unrelated variety and economic growth. Reg Stud 41: 685-697.

- Fujita M, Krugman P, Venables A (1999) The spatial economy. Cities, regions and international trade. MIT Press, Cambridge, MA.

- Geroski PA (1995) What do we know about entry? Int J Ind Organ 13: 421-440.

- Glaeser EL (2000) The new economics of urban and regional growth. In: Clark GL, Feldman MP, Gertler MS (eds) The Oxford handbook of economic geography. Oxford University Press, Oxford, pp. 83-98.

- Glaeser EL, Kallal HD, Scheinkman A, Shleifer A. (1992) Growth in cities. J Political Ec 100: 1126-1152.

- Goldstein H (2003) Multilevel Statistical Models, $3^{\text {rd }}$ edtion. Edward Arnold, London.

- Goldstein H, Rashbash J (1996) Improved approximations for multilevel models with binary responses, J R Stat Assoc, Ser A 159: 505-513. 
- Gordon IR, McCann P (2000) Industrial clusters: complexes, agglomeration, and/or social networks? Urban Stud 37: 513-532.

- Grabher G (1993) Rediscovering the scoial in the economics of interfirm relations. In:

Grabher G (ed.) The embedded firm. On the socioeconomics of interfirm relations. Routledge, London, pp. 1-33.

- Granovetter, MS (1985) Economic action and social structure: the problem of embeddedness. Am J Sociol 81: 481-510.

- Harrison B, Kelley MR, Gant J (1997) Innovative firm behavior and local milieu: exploring the intersection of agglomeration, firm effects, and technological change. Ec Geogr 72: 233-258.

- Helsey RW, Strange WC (1990) Matching and agglomeration economies in a system of cities. Reg Sci Urban Ec 20: 189-212.

- Henderson JV (2003) Marshall’s scale economies. J Urban Ec 53: 1-28.

- Henderson JV, Kuncoro A, Turner M (1995) Industrial development in cities. J Political Ec 103: 1067-1085.

- Heckman JJ (1976) The common structure of statistical models of truncation, sample selection and limited dependent variables and a simple estimator for such models. Ann Ec Soc Meas 5: 475-492.

- Hoover EM (1948) The Location of Economic Activity. McGraw Hill, New York.

- Hox JJ (2002) Multilevel analysis: techniques and applications. Erlbaum, Mahwah, NJ.

- Illeris S (1996) The service economy: a geographical approach. John Wiley \& Sons, Chichester.

- Isard W (1956) Location and space-economy. MIT Press, Cambridge, MA. 
- Jones K (2004), An introduction to statistical modelling. In: Somekh B, Lewin C (eds) Research methods in the social sciences. Sage, London, pp. 236-251.

- Katz ML, Shapiro C (1985) Network externalities, competition and compatibility. Am Ec Rev 75: 424-440.

- Kelley MR, Helper S (1999) Firm size and capabilities. Regional agglomeration and the adoption of new technology. Ec Innov N Tech 8: 79-103

- Lambooy JG (1993) The organisation of firms and spatial agglomeration. Department of Economics, University of Amsterdam, Amsterdam, Research Memorandum, No. 1993-7.

- Lucas RE (1988), On the mechanics of economic development. J Monetary Ec 22: 3-42.

- Macintyre S, MacIver S, Sooman A (1993) Area, class and health: should we be focusing on places or people? J Soc Policy 22: 213-234.

- Marshall A (1890) Principles of economics. MacMillian, London.

- Martin P, Ottaviano JP (2001) Growth and agglomeration. Int Ec Rev 42: 947- 968.

- Martin P, Mayer T, Mayneris F (2008), Spatial concentration and firm-level productivity in France. CEPR Discussion Paper 6858, June 2008.

- McCann P, Van Oort, FG (2009), Theories of agglomeration and regional economic growth: a historical review. In: Capello R and Nijkamp P (eds) Handbook of Regional Growth and Development Theories. Edward Elgar, Cheltenham, UK, Chapter 1.

- McGahan AM, Porter ME (1997), How much does industry matter really?, Strateg Manag J 18 (Summer Special Issue): 15-30.

- Melo PC, Graham DJ, Noland RB (2008), A meta-analysis of estimates of agglomeration economies, Reg Sci Urban Ec 39: 332-342. 
- Miles I, Kastrinos N, Flanagan K, Bilderbeek R, Den Hertog P, Huntink W, Bouman M (1995), Knowledge intensive business services: their roles as users, carriers and sources of innovation. Report to DG13 SPRINT-EIMS, PREST, Manchester, March 1995.

- Mion G, Naticchioni P (2009), The spatial sorting and matching of skills and firms. Can J Ec 42: 28-55.

- Moon G, Subramanian SV, Jones K, Duncan C, Twigg L (2005) Area-based studies and the evaluation of multilevel influences on health outcomes. In: Bowling A, Ebrahim S (eds) Handbook of health services research - investigation, measurement and analysis. Open University Press, Berkshire, pp. 262-296.

- Muller E, Zenker A (2001) Business services as actors of knowledge transformation: the role of KIBS in regional and national innovation systems. Res Policy 30: 1501-1516.

- Mundlak Y (1978) On the pooling of time series and cross-section data. Econometrica 46: 69-85.

- Neffke FMH (2009) Productive places. The influence of technological change and relatedness on agglomeration externalities. PhD Thesis, Utrecht University, Utrecht.

- Ohlin B (1933) Interregional and international trade. Harvard University Press, Cambridge, MA.

- Ponds R, Van Oort FG, Frenken K (2007) The geographical and institutional proximity of research collaboration. Pap Reg Sci 86: 423-444.

- Quigley JM (1998) Urban diversity and economic growth. J Ec Perspect 12: 127-138.

- Parr JB (2002) Missing elements in the analysis of agglomeration economies. Int Reg Sci Rev 25: 151-168.

- Raspe O, Van Oort FG (2009) Growth of new firms and spatially bounded knowledge externalities. Working Paper, Utrecht University. 
- Rashbash J, Browne W, Healy M, Cameron B, Charlton C (2008) MlWin, Version 2.10. Centre of Multilevel Modelling, University of Bristol, Bristol.

- Raudenbush SW, Bryk AS (2002) Hierarchical linear models: applications and data analysis methods.Sage, Thousand Oaks, CA.

- Robinson WS (1950) Ecological correlations and the behavior of individuals. Sociol Rev 15: 351-357.

- Romer PM (1986) Increasing returns and long-run growth. J Political Ec 94: 1002-1037.

- Rosenthal SS, Strange WC (2003) Geography, industrial organization, and agglomeration. Rev Ec Stat 85: 377-393.

- Rosenthal SS, Strange WC (2004), Evidence on the nature and sources of agglomeration economies. In: Henderson JV, Thisse JF (eds) Handbook of regional and urban economics: cities and geography, Volume 4. North Holland, Amsterdam, pp 2119-2179.

- Rumelt RP (1991) How much does industry matter? Strateg Manag J 12: 167-185.

- Santarelli E, Vivarelli M (2007) Entrepreneurship and the process of firm’s entry, survival and growth. Ind Corp Chang 16: 455-488.

- Scott AJ (1988) New industrial spaces. Flexible production organization and regional development in North America and Western Europe. Pion, London.

- Schmalensee RE (1985) Do markets differ much? Am Ec Rev 75: 341-351.

- Snijders TAB, Berkhof J (2007) Diagnostic checks for multilevel models. In: De Leeuw J, Meijer E (eds) Handbook of Multilevel Analysis. Springer, New York, pp. 139-173.

- Snijders TAB, Bosker RJ (1999) Multilevel analysis: an introduction to basic and advanced multilevel modelling. Sage, London.

- Stam E (2005) The geography of gazelles in the Netherlands. J Ec Soc Geogr 96: 121-127. 
- Van Oort FG (2004) Urban growth and innovation: spatially bounded externalities in the Netherlands. Ashgate, Aldershot.

- Van Oort FG (2007) Spatial and sectoral composition effects of agglomeration economies. Pap Reg Sci 86: 5-30. 


\section{Publications in the ERIM Report Series Research* in Management}

\section{ERIM Research Program: "Organizing for Performance"}

\section{0}

Investigating the Perceptions of Credit Constraints in the European Union

Erik Canton, Isabel Grilo, Josefa Monteagudo, and Peter van der Zwan

ERS-2010-001-ORG

http://hdl.handle.net/1765/17699

Two Lighthouses to Navigate: Effects of Ideal and Counter-Ideal Values on Follower Identification and Satisfaction with their Leaders

Niels van Quaquebeke, Rudolf Kerschreiter, Alice E. Buxton, and Rolf van Dick

ERS-2010-003-ORG

http://hdl.handle.net/1765/17702

Genome-wide Association Studies and the Genetics of Entrepreneurship

Matthijs J.H.M. van der Loos, Philipp D. Koellinger, Patrick J.F. Groenen, and A. Roy Thurik

ERS-2010-004-ORG

http://hdl.handle.net/1765/17757

How embodied cognitions affect judgments: Height-related attribution bias in football foul calls

Niels van Quaquebeke and Steffen R. Giessner

ERS-2010-006-ORG

http://hdl.handle.net/1765/17827

Flexible Labor and Innovation Performance: Evidence from Longitudinal Firm-Level Data

Haibo Zhou, Ronald Dekker, and Alfred Kleinknecht

ERS-2010-007-ORG

http://hdl.handle.net/1765/18037

The Influence of Installed Technologies on Future Adoption Decisions: Empirical Evidence from E-Business

Philipp Koellinger and Christian Schade

ERS-2010-012-ORG

http://hdl.handle.net/1765/18463

Seeds of Regional Structural Change: The Role of Entrepreneurs and Expanding Firms in Shaping Local Path Dependencies

Frank Neffke and Martin Henning

ERS-2010-014-ORG

http://hdl.handle.net/1765/19207

Determinants of Contractual Completeness in Franchising

George Hendrikse and Josef Windsperger

ERS-2010-017-ORG

http://hdl.handle.net/1765/19424

Agglomeration and New Establishment Survival: A Mixed Hierarchical and Cross-Classified Model

Martijn J. Burger, Frank G. van Oort, and Otto Raspe

ERS-2010-018-ORG

http://hdl.handle.net/1765/19519

* A complete overview of the ERIM Report Series Research in Management:

https://ep.eur.nl/handle/1765/1

ERIM Research Programs:

LIS Business Processes, Logistics and Information Systems

ORG Organizing for Performance

MKT Marketing

F\&A Finance and Accounting

STR Strategy and Entrepreneurship 